\title{
Analysis of Quantity of Domestic Water Use in Bauchi Metropolis.
}

\author{
Victor Istifanus \\ Department of Environmental Management Technology, Abubakar Tafawa Balewa University Bauchi (ATBU)
}

\begin{abstract}
Water is vital for the survival of all living things. Water shortages are experienced in many urban centers in developing countries due to rapid growth in population, economic development and changes in life style which increase the demand for urban water. However, reliable data on quantity of water used for domestic purpose is difficult to come by in many developing countries. This study therefore intends to provide reliable data on quantity of domestic water use in Bauchi metropolis. The study used stratified systematic random sampling technique to collect data and the data was analyzed using Microsoft Excel software. The study found out that In Bauchi a total of 28,475, 489 million litres of water is used per day for domestic activities. In the low density 5,994,132liters (21\%) of water is used while in the medium and high 10,157,615 (36\%) and 12,323,742 litres (43\%) of water are used respectively daily. At household level, average water use is $511 \mathrm{l} / \mathrm{p} / \mathrm{d}$, while on per capita basis the water use is an average of $68 \mathrm{l} / \mathrm{p} / \mathrm{c} / \mathrm{d}$. Quantity of water use vary within the densities. At household level $878 \mathrm{l} / \mathrm{p} / \mathrm{d}, 439 \mathrm{l} / \mathrm{p} / \mathrm{d}$ and $458 \mathrm{l} / \mathrm{p} / \mathrm{d}$ is used in the low, medium and high of density areas. On per capita basis the average water use in Bauchi is $102 \mathrm{l} / \mathrm{p} / \mathrm{c} / \mathrm{d}, 71 \mathrm{l} / \mathrm{p} / \mathrm{c} / \mathrm{d}$ and $57 \mathrm{l} / \mathrm{p} / \mathrm{c} / \mathrm{d}$ in the low, medium and high density areas respectively. In general the study found out that the distribution of average per capita water in Bauchi metropolis as follows $<50 \mathrm{l} / \mathrm{p} / \mathrm{c} / \mathrm{d}$ 27\%, $50 \mathrm{l} / \mathrm{p} / \mathrm{c} / \mathrm{d}-75 \mathrm{l} / \mathrm{p} / \mathrm{c} / \mathrm{d} 32 \%, 75 \mathrm{l} / \mathrm{p} / \mathrm{c} / \mathrm{d}-100 \mathrm{l} / \mathrm{p} / \mathrm{c} / \mathrm{d} 20 \%, 100$ $\mathrm{l} / \mathrm{p} / \mathrm{c} / \mathrm{d}-150 \mathrm{l} / \mathrm{p} / \mathrm{c} / \mathrm{d} 17 \%, 150 \mathrm{l} / \mathrm{p} / \mathrm{c} / \mathrm{d}-200 \mathrm{l} / \mathrm{p} / \mathrm{c} / \mathrm{d} 3 \%$, and above $200 \mathrm{l} / \mathrm{p} / \mathrm{c} / \mathrm{d} 1 \%$.
\end{abstract}

Keywords: domestic, quantity, water use.

\section{Introduction}

Water is vital for the survival of all living things (Abrashinsky,2004),It is certain that societies are going to have to confront ,among other things, demographic transitions, geographical shift of population, technological advancement growing globalization, growing globalization, degradation of the environment and emergence of water scarcities. Therefore, rapid growth in population, economic development and changes in life style have been responsible for the rapid growth in water demand use in many developing countries in the face of shrinking supplies due to over-exploitation and pollution (Shaban and Sharna, 2007). Although water is abundant covering two-third of the planet ( $97 \%$ salt water), a very small proportion of this ( $1 \%$ fresh water) is affectively available for human use. In Bauchi metropolis, as a result of socio- economic development, the demand for water is increasing more than supply. For instance while the supply of water by Bauchi State Water Board (BSWB) is only 13,388 383 litres, BSWB, (2014), the demand for domestic water as the study is $28,475,489$ litres. The emerging scarcity of water has raised a host of issues related to sustained water supply data on quantity of domestic water use, water financing, equity and social justice, pricing, governance and management. In its guidelines for drinking- water quality WHO (2003) defines domestic water as water being used for usual domestic purposes including consumption, bathing and food preparation. The importance of adequate water quantity for human health has been recognized for many years and there has been extensive debate about the relative importance of water quantity, water quality and sanitation and hygiene in protecting and improving health (Esrey, 1991). Despite this debate, international guidelines or norms for minimum water quantities that domestic supplies should provide remain largely lacking. For instance, while the millennium declaration goals of the United Nation (UN ) in the year 2000, include a target to "halve the proportion of people who are unable to reach or afford safe drinking water by 2015 , it does not specify in what quantity such water should be supplied. The World Health Organization/United Nations Children and Educational Fund (WHO/UNICEF) Joint Monitoring Programme which produces the Global Assessment of water supply and sanitation data described reasonable access as being the availability of at least 20litres per person per day from a source within a kilometres of the user's dwelling (WHO and UNICEF 2000). It should however, be noted that the definition relates primarily to access and should not necessarily be taken as evidence that 20 litres per capita day is a recommended quantity of water for domestic use (WHO, 2003). Bauchi metropolis like many other cities in Nigeria does not have accurate water use figures that could be used for improvement of sustainable water supply system. This study mainly focused on the consumption of domestic water in Bauchi metropolis. It intended to establish the quantity of water use at household and per capita level. The will be useful for upgrading the water supply scheme, planning the expansion of water treatment plant as well as storage and distribution system. 


\section{Methodology}

Bauchi has a population of 418,037 living in 52,254 households (National Population Commission (NPC), 2006). A stratified random sampling was used for this study. A total of 381 households were sampled (Krejuice and Morgan, 1970). The city was categorized into residential densities with low density (54), medium density (130) and high density (197) samples. Since water supply to Bauchi metropolis is not metered the questionnaire method is used. The data collection was carried out over a period of three weeks (3) from May to June, 2015 with the help of six (6) trained research assistants. The data was collected through structured questionnaires for the water board and households. For the water Board it was administered to the General Manager of Bauchi State Water Board (BSWB). The head of households were the target respondents at household level. The volume of containers in which households store water were measured and the number of containers of water used for the different activities were ascertained. Where running tap water was used activities, such as showers and kitchen or dinning tap, the duration for which the tap was used was arrived at and the quantity of water per minute coming out from the tap was measured. By multiplying the time with the quantity of water per minute, the volume of water use was estimated. It is assumed that the quantity of water supplied were used for various domestic activities.

The quantity of water used in a toilet was assessed by the volume of bucket used for flushing or the flush tank capacity Old flush tank systems had 9 litres and new flush tanks has 6 litres capacity. The frequency of use was also obtained and by multiplying the frequency of use and the capacity of container used the volume of water here was also estimated. Where the toilet is a pit latrine the volume of bottle or kettle used was utilized. For bathing, cloth washing, dish- washing, cooking and so on, the volumes of container utilized were used to estimate the quantity of water used for such activity. For ablution or Muslim prayer and other religions rituals, the volume of bottle, kettle or container was used to estimate the quantity of water for such activity. Other information were obtained directly from interaction with users of water.

\section{Domestic Water Use Standards and Consumption.}

Domestic water use standards in any society varies with climatic condition, life style, culture, tradition, technology and economy. There is no fixed data to estimate the amount of water needed to maintain acceptable minimum living standard (Zhang, 1999 \& WHO, 2003). But because of its fundamental role in human development, the world community put forward the "basic need for water" concept as the guideline to determine water use standards more than twenty years ago (Gleick, 1996). Gleick (1996) estimates the total Basic Water Requirement (BWR) at $50 \mathrm{~L} / \mathrm{p} / \mathrm{c} / \mathrm{d}$ for meeting four domestic basic needs: drinking, sanitation, bathing and cooking, independent of climate, technology and culture. Falkenmake uses the figure of $100 \mathrm{~L} / \mathrm{p} / \mathrm{c} / \mathrm{d}$ for personal use as a rough estimate of the amount needed for a minimally acceptable standard of living in developing countries (Zhang, 2005). The Nigeria National water policy on water supply and sanitation (2004) sets consumption standards: $30 \mathrm{l} / \mathrm{p} / \mathrm{c} / \mathrm{d}$ within $250 \mathrm{~m}$ for rural areas; $60 \mathrm{l} / \mathrm{p} / \mathrm{c} / \mathrm{d}$ with limited pipeline reticulation or full house connections and $120 \mathrm{l} / \mathrm{p} / \mathrm{c} / \mathrm{d}$ served with full reticulation in consumer premises for urban areas.

Per capita daily water use shows a great variation among different economies and regions. Generally speaking in developing regions of the world people use far less water per capita than those in the developed world. In Africa the average consumption standard is $47 \mathrm{~L} / \mathrm{p} / \mathrm{c} / \mathrm{d}$ and in Asia the Figure increases to $85 \mathrm{~L} / \mathrm{p} / \mathrm{c} / \mathrm{d}$. In contrast, in developed countries such as U.K comparable water use is estimated at $334 \mathrm{~L} / \mathrm{p} / \mathrm{c} / \mathrm{d}$ and in the U.S.A, it is $547 \mathrm{l} / \mathrm{p} / \mathrm{c} / \mathrm{d}$ (Otaki et al., 2010).

Despite these WHO, (2009) and NWP, (2004) set that $120 \mathrm{~L} / \mathrm{p} / \mathrm{c} / \mathrm{d}$ is required to maintain healthy living condition in urban center . Domestic water consumption varies from country to country. In New Zealand average domestic water consumption is $180 \mathrm{~L} / \mathrm{p} / \mathrm{d}$, in Australia it is $270 \mathrm{~L} / \mathrm{p} / \mathrm{day}$ in England and Wales it is 150 $\mathrm{L} / \mathrm{p} / \mathrm{d}$ and in China it is $230 \mathrm{~L} / \mathrm{p} / \mathrm{d}$. (Lu, 2007). In the European Union the variation of water consumption was $138 \mathrm{l} / \mathrm{p} / \mathrm{c} / \mathrm{d}$ in Denmark and $128 \mathrm{l} / \mathrm{p} / \mathrm{c} / \mathrm{d}$ in 1998 (European Environment Agency 2014). In Barcelonia Spain Gascon et al., (2010) reported an average consumption of 334 litres.

Internationally there are also variations in municipal water consumption. In municipals, water consumption are $190 \mathrm{~L} / \mathrm{p} / \mathrm{d}$, in Auklanland city, in Amsterdam it is $156 \mathrm{~L} / \mathrm{p} / \mathrm{c} / \mathrm{d}$ and in Singapore its 162Lpcd (Lu,2007). In Cairo it is 237 litres more than the African index average of 187 litres (African Green City Index 2015). Even within countries domestic water consumption varies from one city to the other. Shaban \& Sharna (2007) reported water consumption variation among 7 major cities in India. The highest consumption was in

Kolkata $(116 \mathrm{~L} / \mathrm{p} / \mathrm{c} / \mathrm{d})$, Mumbai $(90 \mathrm{~L} / \mathrm{p} / \mathrm{c} / \mathrm{d})$, Mudarai $(88 \mathrm{~L} / \mathrm{p} / \mathrm{c} / \mathrm{d})$ while Kampur consume $(77$ $\mathrm{L} / \mathrm{p} / \mathrm{c} / \mathrm{d}$ ). In the United States household per capita water use range from $200 \mathrm{l} / \mathrm{p} / \mathrm{c} / \mathrm{d}$ in Wisconsin to $80 \mathrm{l} / \mathrm{p} / \mathrm{c} / \mathrm{d}$ in Idaho (Donnelly \& Coolley, 2015) In Nigerian urban centres per capita water use in Ilorin is $86.22 \mathrm{l} / \mathrm{p} / \mathrm{c} / \mathrm{d}$, (Ayanshola et al., 2010) Maiduguri $100 \mathrm{l} / \mathrm{p} / \mathrm{c} / \mathrm{d}$, (Kagu et al., 2013) Owerri $96 \mathrm{l} / \mathrm{p} / \mathrm{c} / \mathrm{d}$ (Onyenechere and Osuji, 2012) and Zaria 54 1/p/c/d (Musa et al., 2012). In Osiele Ogun State, only $16.4 \%$ of residents use more than 40 $\mathrm{l} / \mathrm{p} / \mathrm{c} / \mathrm{d}$ while $83.6 \%$ use less than $40 \mathrm{l} / \mathrm{p} / \mathrm{c} / \mathrm{d}(\mathrm{Ojo}, 2014)$.Despite these WHO, (2009) and NWP, (2004) set that $120 \mathrm{~L} / \mathrm{p} / \mathrm{c} / \mathrm{d}$ is required to maintain healthy living condition in urban centers . 


\section{Quantity of water use}

\section{Results and Discussion.}

In Bauchi, total quantity of 28,475, 489 million litres of water is used per day for domestic activities. In the low density 5,994,132liters (21\%) of water is used while in the medium and high 10,157,615 (36\%) and $12,323,742$ litres $(43 \%)$ of water are used respectively daily (table1). At household level, average water use is $511 \mathrm{l} / \mathrm{p} / \mathrm{d}$, while on per capita basis the water use is an average of $68 \mathrm{l} / \mathrm{p} / \mathrm{c} / \mathrm{d}$. Quantity of water use vary within the densities. At household level $878 \mathrm{l} / \mathrm{p} / \mathrm{d}, 439 \mathrm{l} / \mathrm{p} / \mathrm{d}$ and $458 \mathrm{l} / \mathrm{p} / \mathrm{d}$ is used in the low, medium and high of density areas. On per capita basis the average water use in Bauchi is 102 1/p/c/d , 71 1/p/c/d and 57 1/p/c/d in the low, medium and high density areas respectively (Table 2).

Table 1: Quantity of Total Water Use in Density areas in Bauchi Metropolis

\begin{tabular}{|l|l|l|l|l|l|l|l|}
\hline Low & \% & Medium & \% & High & \% & Total & \\
\hline $\begin{array}{l}\text { Total Water } \\
\text { use }\end{array}$ & $5,994,132$ & 21 & $10,157,615$ & 36 & $12,323,742$ & 43 & $28,475,489$ \\
\hline
\end{tabular}

Table 2: Quantity Water Use in Sampled Household Level in Bauchi Metropolis

\begin{tabular}{|l|l|l|l|l|}
\hline & Low & Medium & High & Bauchi \\
\hline HOUSEHOLD & 878 & 439 & 458 & 511 \\
\hline PER CAPITA & 102 & 71 & 57 & 68 \\
\hline
\end{tabular}

Compared to the NWP (2004) standard of $120 \mathrm{l} / \mathrm{p} / \mathrm{c} / \mathrm{d}$, the $68 \mathrm{l} / \mathrm{p} / \mathrm{c} / \mathrm{d}$ for Bauchi is below the national standard. Further analysis revealed that $88 \%$ of households in Bauchi metropolis are below the national standard of water supply while only $12 \%$ of households are above the national standard (Figure 1). Similarly, compared to the average water of $68 \mathrm{l} / \mathrm{p} / \mathrm{c} / \mathrm{d}$ in Bauchi further analysis revealed that $62 \%$ of households are below and $38 \%$ are above the Bauchi average. (Figure 2). In general the study found out that the distribution of average per capita water in Bauchi metropolis as follows $<50$ l/p/c/d,27\% 50 1/p/c/d-75 1/p/c/d 32\%,75 1/p/c/d-100 1/p/c/d 20\%, 100 l/p/c/d-150 l/p/c/d 17\%, 150 l/p/c/d-200 l/p/c/d 3\%, and above 200 l/p/c/d 1\%. (Figure 3).

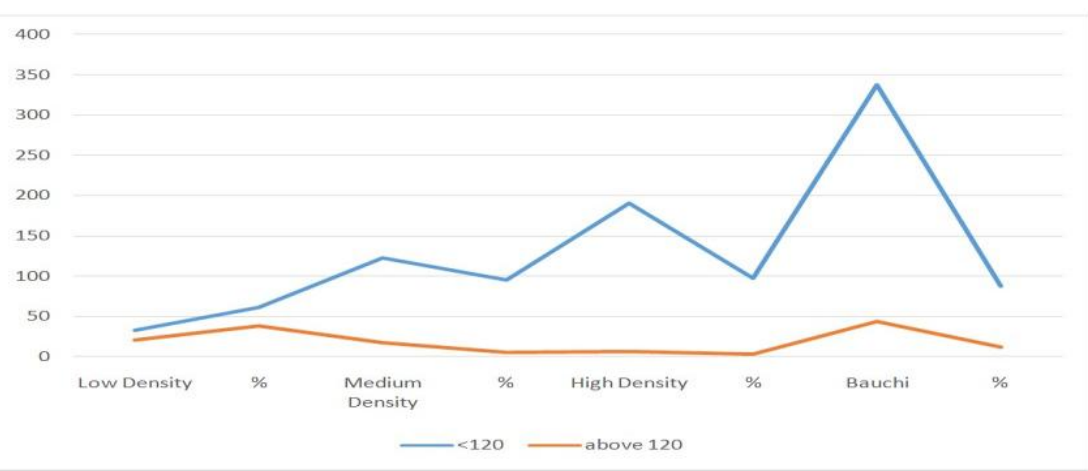

Figure 1: Distribution of per capita water use in households with NWP standard

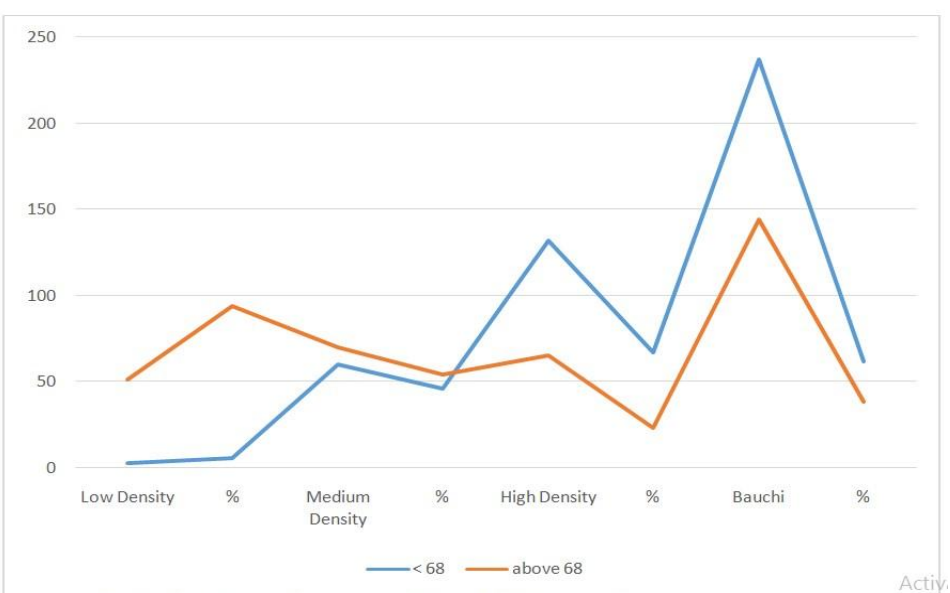

Figure 2: Distribution of per capita water use in household using Bauchi Average 


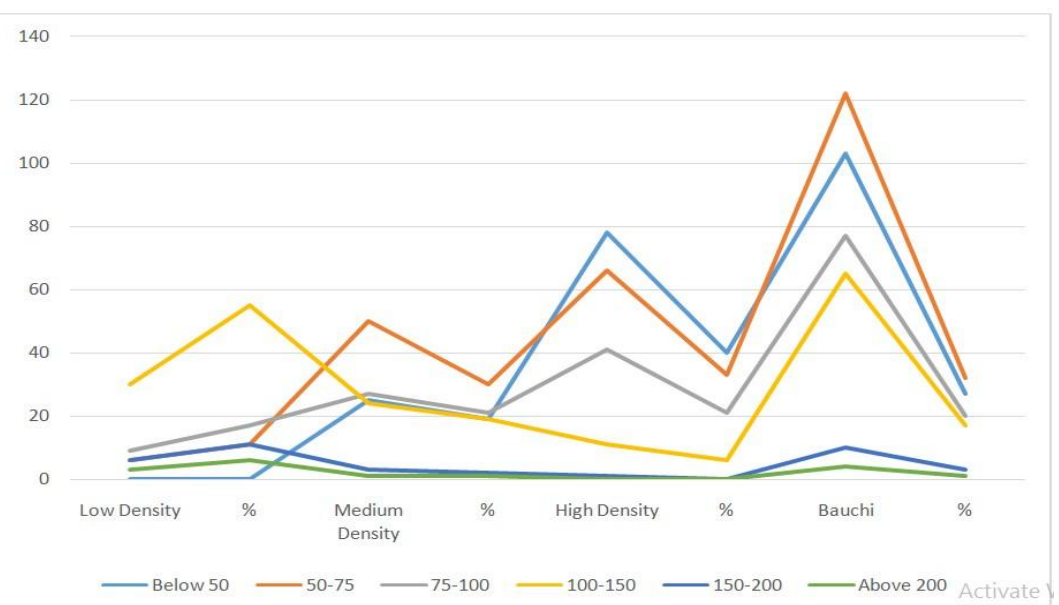

Figure 3: Distribution of per capita water use in households in Bauchi metropolis

The study also found large variation in domestic water use in Bauchi metropolis. At, household level water use ranges from $24 \mathrm{l} / \mathrm{p} / \mathrm{d}$ to $2150 / \mathrm{l} / \mathrm{p} / \mathrm{d}$. Within the density areas the range is $183 \mathrm{l} / \mathrm{p} / \mathrm{d}$ to $2150 \mathrm{l} / \mathrm{p} / \mathrm{d}$ in the low density areas, $24 \mathrm{l} / \mathrm{p} / \mathrm{d}$ to $1156 \mathrm{l} / \mathrm{p} / \mathrm{d}$ in medium density areas and $35 \mathrm{l} / \mathrm{p} / \mathrm{d}$ to $1248 \mathrm{l} / \mathrm{p} / \mathrm{d}$ in high density areas. On per capita basis the range for Bauchi is from $24 \mathrm{l} / \mathrm{p} / \mathrm{c} / \mathrm{d}$ to $247 \mathrm{l} / \mathrm{p} / \mathrm{c} / \mathrm{d}$. Within the densities the range is $62.2 \mathrm{l} / \mathrm{p} / \mathrm{c} / \mathrm{d}$ to $247 \mathrm{l} / \mathrm{p} / \mathrm{c} / \mathrm{d}, 24 \mathrm{l} / \mathrm{p} / \mathrm{c} / \mathrm{d}$ to $208 \mathrm{l} / \mathrm{p} / \mathrm{c} / \mathrm{d}$ and $25.6 \mathrm{l} / \mathrm{p} / \mathrm{c} / \mathrm{d}$ to $168.4 \mathrm{l} / \mathrm{p} / \mathrm{c} / \mathrm{d}$ in the low, medium and high density areas respectively (Table 3 ). The reasons of high capita water use in the low density areas and the relative low per capita water use in the medium and high density areas is also because of the relative high living standard in the low density areas in the relative low living standards in the medium and high density areas respectively.

Table 3: Variation in domestic water use in Sampled Household Level in Bauchi Metropolis

\begin{tabular}{|l|l|l|l|l|l|l|l|l|}
\hline Household & Density & & & & & & & \\
\hline Water & Low & Medium & High & Bauchi & & & & \\
\hline Use & High & Low & High & Low & High & Low & High & Low \\
\hline Household & 2150 & 183 & 1156 & 24 & 1248 & 35 & 2150 & 24 \\
\hline Per capita & 247 & 62.2 & 208 & 24 & 168.4 & 25.6 & 247 & 24 \\
\hline
\end{tabular}

In general variation in water use all levels are very wide. At density level total domestic water use per day are 5,994,132 (21\%), 10,157,615 (36\%) and 12,323,742 (43\%) in the low, medium and high density areas respectively (Table1). At household level average domestic water use are 878 1/p/d ,437 1/p/d and 458 1/p/d in the low, medium and high density areas respectively. On per capita basis, an average of $102 \mathrm{l} / \mathrm{p} / \mathrm{c} / \mathrm{d}, 71 \mathrm{l} / \mathrm{p} / \mathrm{c} / \mathrm{d}$ and $57 \mathrm{l} / \mathrm{p} / \mathrm{c} / \mathrm{d}$ are used in the low, medium and high density areas respectively (Table 2). The average per capita water use of 681/p/c/d in Bauchi metropolis fall short of the recommend $120 \mathrm{l} / \mathrm{p} / \mathrm{c} / \mathrm{d}$ of the (WHO, 2009) and the National Water Policy (NWP, 2004). Further analysis revealed that $88 \%$ of household in Bauchi metropolis use water below the national standard while only $12 \%$ of households are above the national standard (Figure 1). Within the densities $61 \%, 95 \%$ and $97 \%$ of households are below the national standard within the low, medium and high density areas respectively, while $39 \%, 5 \%$ and $3 \%$ of households are above the national standard in the low, medium and high density areas respectively (Figure 1). Comparison of households with the Bauchi average of $68 \mathrm{l} / \mathrm{p} / \mathrm{cd}, 62 \%$ of households were found to be below the Bauchi average while $32 \%$ were above the Bauchi average in the low, medium and high density areas respectively. Within the densities $94 \%, 54 \%$, and $23 \%$ of household were found to be above the Bauchi average while 6\%,46\% and $67 \%$ of household were found to be below the Bauchi average in the low medium and high density areas respectively also (Figure 2). Similarly further analysis found the general distribution of per capita water use to be as follows. In Bauchi $27 \%$ use less than $50 \mathrm{l} / \mathrm{p} / / \mathrm{cd} .32 \%$ use $50 \mathrm{l} / \mathrm{p} / \mathrm{c} / \mathrm{d}-75 \mathrm{l} / \mathrm{p} / \mathrm{c} / \mathrm{d}, 20 \%$ use $75 \mathrm{l} / \mathrm{p} / \mathrm{c} / \mathrm{d}-100 \mathrm{l} / \mathrm{p} / \mathrm{c} / \mathrm{d} .17 \%$ use $100 \mathrm{l} / \mathrm{p} / \mathrm{c} / \mathrm{d}-150 \mathrm{l} / \mathrm{p} / \mathrm{c} / \mathrm{d}$ while $3 \% 1 \%$ use 150 1/p/c/d-200 1/p/c/d and above $2001 \mathrm{p} / \mathrm{c} / \mathrm{d}$ respectively. Within the densities $0 \%, 1 \%$ and $40 \%$ use water less than $50 \mathrm{l} / \mathrm{p} / \mathrm{c} / \mathrm{d}$ in the low, medium and high density areas respectively, while $11 \%, 30 \%$ and $33 \%$ use water between $501 \mathrm{p} / \mathrm{c} / \mathrm{d}-75 \mathrm{l} / \mathrm{p} / \mathrm{c} / \mathrm{d}$ in the low, medium and high density areas respectively. Similarly $6 \%, 1 \%$ and $0 \%$ use water above $200 \mathrm{l} / \mathrm{p} / \mathrm{c} / \mathrm{d}$ in the low, medium and high density areas respectively also. (Figure 3). The reason for low values of per capita water use in the high and medium density areas can be attributed to low living standard and for the relative high per capita value in low density areas to the high living standard there. 
From the above discussion it is obvious that water shortage exist in terms of quantity supplied and the NWP standard. Water is critical for managing the environment in terms of sewage disposal, landscaping, maintenance of parks and gardens, personal hygiene and environmental sanitation. Indeed any activity that that affects water affects the environment. For example when people are faced with shortage of water supply from public source they have no choice but look for alternative sources such as streams, wells, boreholes and water vendors with it numerous problems.

\section{Conclusion and Recommendation}

From the above discussion it is obvious that water shortage exist in terms of quantity supplied and the NWP standard. Water is critical for managing the environment in terms of sewage disposal, landscaping, maintenance of parks and gardens, personal hygiene and environmental sanitation. Indeed any activity that that affects water affects the environment. For example when people are faced with shortage of water supply from public source they have no choice but look for alternative sources such as streams, wells, boreholes and water vendors with it numerous problems. It is therefore recommended that policy makers and water supply planners should increase the quantity of water supplied to the metropolis by expanding existing water supply schemes and establish new ones through improved budgetary allocation.

\section{Reference}

[1] Abrashinsky, N. (2004). Domestic Use of Water, International Environmental Problems and Policy, University of Wisconsiri-E and Claire USA.

[2] African Green City Index (2015). Assessing the performance of Africas Major Cities, Economist Intelligence Unit Scimens Cairo Egypt.

[3] Ayanshola, A.M F. \& Salami, A.W. (2010). Modelling of Domestic Water Demand at Household Level in Illorin Nigeria. Retrieved May 6, 2014 from http://www.unilorin.edu.ng/publications/ayanshola/modelyofresident

[4] Bauchi State Water Board (BSWB), (2014). Communication with the General Manager (BSWB).

[5] Donnelly, K. \& Cooley, H. (2015). Water Use Trends in the United States, Pacific Institute. USA.

[6] Esrey G. A, Potash J.B, Roberts L. \& Shif F.C. (1991). Effects of Improved water supply and sanitation an ascariasis, diarrhoea, draculiasis, hookworm infection, schistomasis and trachoma,. bulletiri of the World Health Organization, 69(5): 609-621.

[7] European Environment Agency. (2014). Household water use-background and data. Retrieved February 6, 2014, from http://www.environment-agencygov.uk/yourenv/432430/432434/432453/434390/?/ang<eN>:

[8] Gascon, L, Arregui, F, Cobacho, R, \& Canbrera, J.E. (2010). Instituto Tecnologicodel Agua, Universidad Politecnica de Valencia Spain Farreguia ita.upv.es.

[9] Gleick, P. H. (1996). Water Requirement for Human Activities: Meeling Basic Needs;. Water International (IWRA) 21: 83-92.

[10] Kagu, A. Badawi, H. L. \& Abba, J. M. (2013). Assessment of waste- water disposal in some selected wards of Maiduguri metropolis, borno state, Nigeria. Journal of Geography and Geology, 5(4), 83-95.

[11] Lu, T. (2007). Research of Domestic Water Consumption: A Field study in Harbin China. Unpublished M.sc project at Loughborough University U.K. U.K.

[12] Musa, I.J., Shehu, A. \& Lukman, S. (2012). The Distribution Methods and Supply Problems of Tap Water in Urban Zaria Areas, Kaduna State. Electronic Journal of Environmental, Agricultural and Food Chemistry.

[13] National Water Policy (NWP) 2004, Federal Republic of Nigeria, Federal Ministry of Water Resources Abuja.

[14] Ojo, O.M. (2014). Availability and use of Domestic Water in Osiele Areas of Ogun State, Nigeria. Research Journal in Engineering and Applied Sciences, 3(2), 104-107.

[15] Otaki, Y, Otaki, M., Aramaki, T. \& Sakura, O. (2010). Domestic Water Demand Analysis by Household Activities. Tokyo: University of Tokyo Inter Faculty Initiative on Information Studies.

[16] Shaban, A. \& Sharma, R.N. (2007). Water Consumption Patterns in Domestic Household in Major Cities. Journal of Economic and Political Weekly.

[17] World Health Organization (W.H.O). (2000). Water Supply and Sanitation Global Water and Sanitation Assessment. UNICEF, New York.

[18] World Health Organization. (W.H.O). (2003). Retrieved July 21, 2015, from Domestic Water Quantity, Service, Level and Health: from http://www.who.int/watersanitationhealth/

[19] World Health Organization. (W.H.O). (2009). Water Recreation and Disease IWA Publishing London.

[20] Zhang, H.H. (1999). Nine Dungons one river; The Role of Institutions in Developing Water Pricing Policy in Beijing PRC. Published by McGill University

[21] Zhang, H.H. (2005). Domestic Urban Water Use. It Implication for Municipal Water Supply in Bejing. Journal of Habitat International. 